\title{
高解像度入カしたカラー印刷文書画像に現れる網点ノイズの効 果的軽減手法
}

\section{An Effective Mesh Noise Reduction Method for High Resolution Color Document Images}

\author{
正会員 長 谷 博 行 ${ }^{\dagger}$, \\ 丸山博 ${ }^{\dagger}$, \\ 米田政明 ${ }^{\dagger}$,
}

酒 井充 ${ }^{\dagger}$,

Hiroyuki Hase $^{\dagger}$, Masaaki Yoneda ${ }^{\dagger}$, Mitsuru Sakai ${ }^{\dagger}$, Hiroshi Maruyama ${ }^{\dagger}$ and Jien Kato ${ }^{\dagger \dagger}$

\begin{abstract}
あらまし 高解像度で入力されたカラー印刷文書画像に現れる網点ノイズを効果的に軽減する手法を提案した。まず，色を均一に するために平滑化による効果を評価した。しかし，これは画像にボケをもたらすため，ボケを防ぎかつ平均化を行う選択的局所色平均 化法を提案し，実験によりその有効性を示した。
\end{abstract}

キーワード : 解像度, カラー文書画像, 色置換, 選択的局所平均化法

\section{1. まえ がき}

OCR はこれまで白色の背景に黒色の文字で書かれた 文書に対して開発されてきた。今後実現されるであろう カラー対応 OCR においても従来と同様 $400 \mathrm{dpi}$ 程度の 解像度が必要になると考えられるが，オフセット印刷さ れたカラー文書画像からこのような高解像度で色を取得 した場合，各画素值には印刷に用いたインクの網点が現 れ，色に基づく領域分割の際に問題となる。本論文では その対策について述べる.

一般に書店などにある書籍，雑誌等の表紙のほとんど がオフセット印刷されている.オフセット印刷は色によ り異なった角度の網状に配置されたドットの面積と密度 で濃度を表現し, シアン, マゼンタ, イエロー, ブラック の 4 色の減色混合と加色混合を利用して色を表現してい る. 寸なわち, 複数のインクが重なった部分は減色混合 となり，空間的に重なりをもたない色は加色混合となっ て我々の目に入る。網の目の粗さは通常 175 線/インチ (175 lpi, $350 \mathrm{dpi}$ 相当 $\left.{ }^{1)}\right)$ であり，見た目に単一色に見え る色でも拡大して見ると網点を見ることができる。

例として，付·図 1(a) には見た目に均一な色を $50 \mathrm{dpi}$

2000 年 3 月 21 日受付, 2000 年 5 月 8 日再受付, 2000 年 5 月 22 日採録 $\dagger$ 富山大学 工学部

（䎡 930-8555 富山市五福 3190,TEL 076-445-6737) ††名古屋大学 大学院 工学研究科

( 于 464-8603 名古屋市千種区不老町,TEL 052-789-5144)

$\dagger$ Faculty of Engineering, Toyama University

(3190, Gofuku. Toyama-shi. Toyama 930-8555. Japan)

$\dagger \dagger$ Department of Information Engineering, Nagoya University

(Furou-chou. Chikusa-ku, Nagoya-shi, Aichi 464-8603, Japan)
の解像度で入力した画像 $(50 \times 50$ 画素) を示すが*, (b) は (a) の画像の $\square$ 印の領域 (約 $1.3 \mathrm{~mm}$ 角) を光学的に拡 大した網点画像である。(c) は (a) の画像を 400dpi でイ メージスキャナから取得し, 画像処理ソフト Photoshop で各画素の色がわかるくらいに拡大した画像である。こ のように，高解像度でカラ一画像を入力すると印刷時の インクの色が画素值に現れることがわかる。(d) は (a) の画像を $50 \mathrm{dpi}$ で入力し (c) と同じ率で拡大したもので ある。(d) からわかるように, 50dpi 程度の低解像度では 寸べての画素はほぼ均一な色になっていて画素境界がわ からないほどであるが，各画素の大きさは(c)と同じで ある。

本論文では，カラー印刷文書画像を見た目の色で，か つ高解像度で入力する方法について検討する。一般に雑 音を除去するには平滑化や内挿法が考えられるが，平滑 化は画像にぼけを生じさせる。一方, 内挿法は雑音成分 が明らかでなければならないが，付・図 1(c) のように 網点ドットは画像全体にわたって観測され，雑音成分を 明らかにすることはできない，ぼけを生じさせずに平滑 化する方法はこれまでにもいくつか考えられてきた。 そ れらは選択的局所平均化法と呼ばれ，例えば，前もって 周波数成分の高いエッジや線を検出しておき，それらが 存在しない領域を平均化する方法や，注目画素の近傍領 域をいくつかに分割し分散值の小さな分割領域の平均值 に注目画素の画素值を置き換える方法などである ${ }^{21}$ 。し

\footnotetext{
*電子的に入力し印刷したものは，いくつかの原因により本来の色之若干異な る.この問題は本論文の目的上関係がないので，サンブルはす心゙電子的に 入力され印刷されたもの在提示する。
} 


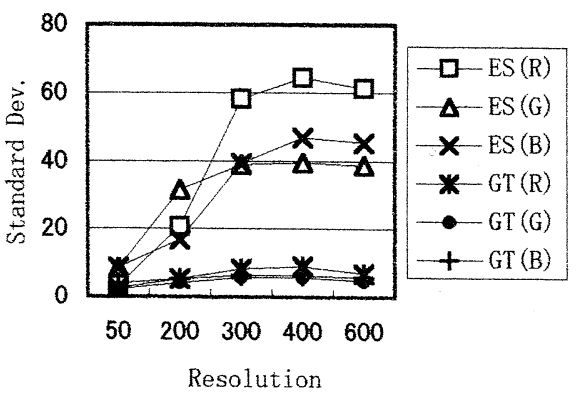

(a) Color 1(rr)

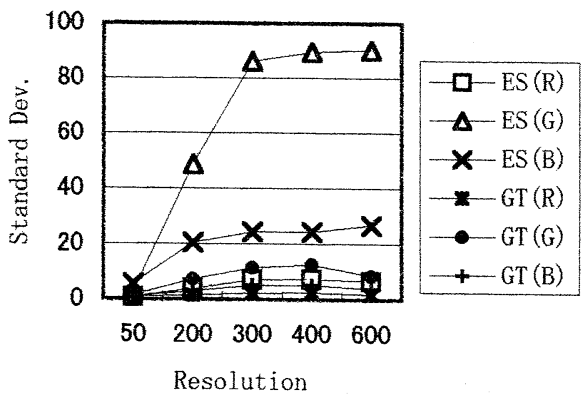

(c) Color 3(yr)

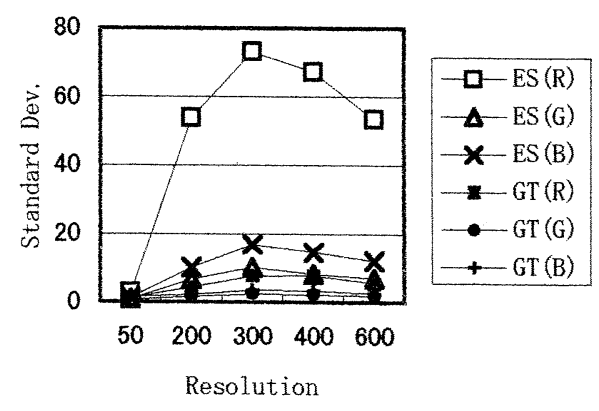

(b) Color 2(gb)

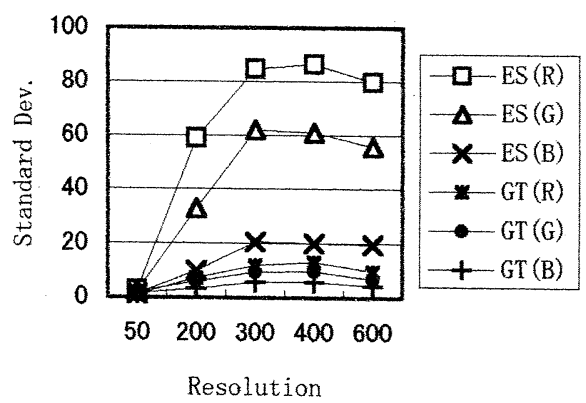

(d) Color 4(lb)

図 1 解像度上 R, G,B 色分布门標準偏差

Standard deviations of R.G.B color distributions

かし，平均化すべきものとそうでないものは研究対象に よって異なり，必然的にアルゴリズムも異なる。本研究 で提案するアルゴリズムはこの選択的局所平均化法の分 類に属し，カラー文書画像を対象として全画像面を平均 化操作するが，それは局所的同質領域においてなされる.

高解像度カラ一印刷文書画像を対象とした報告は少な い. 文献 3) は雑誌のカラー表紙などから 400dpi で入力 した高解像度カラー文書画像を対象としている。しかし, この報告では色情報を捨て, 網点ノイズの影響を軽減す るため光学解像度の低いイメージスキャナを用いていて, スキャナ性能が変わると処理条件が変わる恐れがある。

本研究で使用する画像入力装置はイメージスキ ヤナ (EPSON 社製 ES2000，光学解像度 1600dpi と同 GT8500, 光学解像度 $600 \mathrm{dpi}$; 以降それぞれ ES,GT と記 す)である. また, 照明条件の均一性が求められるため, イメージスキャナ以外の入力装置は考えないことにする.

\section{2. 色成分ごとの分布の解像度依存性}

高解像度でカラー印刷画像を入力した場合, 均一に見 える色でも各画素の色值は大きく異なる，そこで，解像 度を変えて R,G,B の分布の標準偏差を測定したところ 図1のような結果が得られた。図 1 では色相の異なった 見た目に均一な 4 色 (付 ·図 2 参照) を選び，上記の 2 つ のイメージスキャナを用いて測定した。なお，付·図 2 の 4 つのサンプル画像において, 右は左の画像の一部を 拡大したものである. 図 1 の各グラフは付.図 2 に示寸
各画像パターンに対応している. 図 1 より光学解像度 1600dpi のスキャナES の方が光学分解能が高いため, ど の色においてもばらつきが極めて大きいことがわかる. また，400dpi までは解像度が大きくなるに従って R,G,B それぞれの標準偏差值が大きくなる傾向にあることがわ かる、これは印刷時のインクの色が徐々に現れてくるこ とを意味する。しかし 600dpi では逆に標準偏差が僅か に小さくなる傾向があるが，これは印刷の網点の周波数 成分が 350dpi 付近で最大を示すためであると考えられ る。本論文では, カラー対応 OCR を目標としているの で，350dpi 程度のスキャナ特性を考慮に入れる。

色空間あるいは画像空間において画素値に基づき領域 分割する場合, 色分布が解像度により異なると領域分割 するためのパラメータが解像度に依存することになる. そのため次章では, 解像度による色分布の違いを吸収す ることを目的として, 平滑化による色置換について検討 する。

\section{3. 平滑化による色置換}

イメージスキャナの解像度が $R(\mathrm{dpi})$ に設定されてい るとき, CCD センサはその解像度でマップされた各点 を中心として，その周辺の領域を積分する形で各画素值 を決定する. そのため, $50 \mathrm{dpi}$ 程度の低解像度では光学 的に広く積分することにより網点の原色が隠蔽され，各 画素值は見た目に原画像と同様の色となる。高解像度に おいても, 網点の原色が隱蔽された状態の画像が得られ 


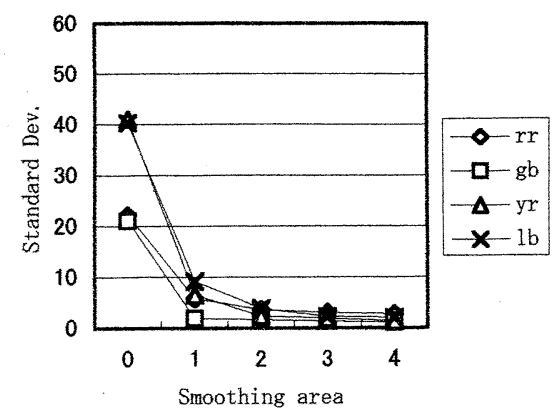

(a)300dpi

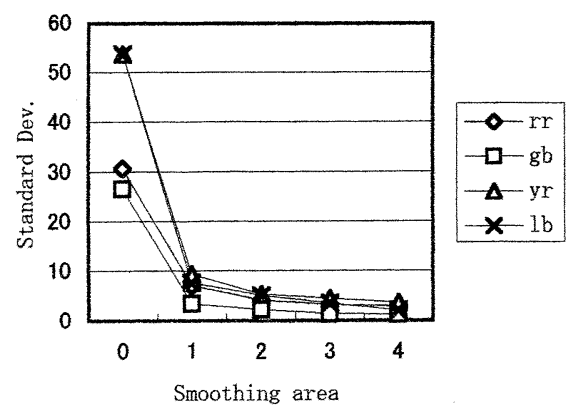

(b) $400 \mathrm{dpi}$

図 2 平滑化の効果

Effect of the smoothing.

ればよいと考える．本章ではこれを目的として画素值の 置換を行う.

基本的な考え方は, 局所領域の積分により均一な画 素值を得ることである。この目的に従って実験を行っ た。実験には付.図 2 に示した見た目に一様な 4 色を用 い，図 1 で大きな標準偏差を示した光学解像度 1600dpi のイメージスキャナES を用い, 300dpi と 400dpi で取 得した画像に対して実験を行った。結果を図 2 に示す. 図 2 において, 横軸は周辺の積分領域の範囲を表して おり，例えば横軸の值を $i$ とすると，中心画素に対して $(2 \cdot i+1) \times(2 \cdot i+1)$ の範囲の值の平均をとることを意 味する. 縦軸は画像の色值を濃淡値に変換して求めた標 準偏差である。図 2 は本来ならば図 1 のように R, G,B の各色ごとに表示すべきであるが，濃淡值は RGB 值 の線形結合であり, 濃淡值の標準偏差から RGB 值の標 準偏差の大小が類推できると判断したことと, 紙面の 節約のため濃淡值の標準偏差で示した．グラフのパラ メータは 4 つのサンプル画像を表している. グラフより， $3 \times 3(i=1)$ の領域を積分することで $i=0$ の場合の標淮 偏差の約 $1 / 4$ に急激に減少することがわかる。このこと は, 網点が 175lpi(350dpi 相当) で印刷されているため, 300dpi あるいは 400dpi の画像においては 1 つの画素の 8 近傍にほぼ他のすべての色が存在していることからも 推察できる. その後, 積分領域を大きくしていくと標準 偏差值は徐々に小さくなり, $9 \times 9(i=4)$ の積分範囲にお いてほぼ図 1 に示す $50 \mathrm{dpi}$ 画像の標準偏差に相当する値 となる. 光学解像度 $600 \mathrm{dpi}$ のイメージスキャナ GTに おける実験においても同様の傾向が得られている.

\section{4. 選択的局所色平均化アルゴリズム}

前章において $3 \times 3$ の局所領域を積分することで画素 值の標準偏差が約 $1 / 4$ になることがわかった．画素值の 均一化としてはまだ不充分であるが，これ以上平滑化を 続けると画像はかなりぼけてしまう。 カラー文書には小 さな文字が書かれることもあり，大きなぼけは認識率の 低下につながる。
本論文では，カラー文書画像の平滑化とぼけの防止を 目的とした選択的局所色平均化 (Selective Local Color Averaging;SLCA と記す) アルゴリズムを提案する. 基 本的な考え方は平滑化する領域を選択的に決定すること である.

前処理として $3 \times 3$ のマスクにより一度平滑化したカ ラー画像を $f$ とし, 注目点を $(i, j)$ とする. SLCA アル ゴリズムを以下に示す.

手順 1 注目点を中心に $N \times N$ の局所領域を考光, $M=N^{2}$ 個の画素值を濃淡值に変換し 1 次元配 列 $h(k)(k=1, \ldots, M)$ に格納する. その際, 座標 值も同時に記憶し, 注目画素の要素を $k^{*}$ とする.

手順 21 次元配列を濃度值に基づき並べ替える. 並べ 替えは昇順でも降順でもよい。

手順 31 次元配列を点 $\hat{k}$ で 2 分し, $k=1, \ldots, \hat{k}$ と $k=\hat{k}+1, \ldots, M$ の各群で濃度值の平均 $\mu_{1}, \mu_{2}$ と分 散 $\sigma_{1}^{2}, \sigma_{2}^{2}$ を計算する.

手順 4 評価值

$$
\eta(\hat{k})=\frac{\left|\mu_{1}-\mu_{2}\right|}{\sqrt{\left(n_{1} * \sigma_{1}^{2}+n_{2} * \sigma_{2}^{2}\right) / M}}
$$

を $\hat{k}=1, \ldots, M-1$ について計算する.ただし， $n_{1}(=\hat{k}), n_{2}(=M-\hat{k})$ は各群の画素数である.

手順 5 評価值 $\eta$ が最大の点 $\hat{k}_{\text {max }}$ を求める.

手順 6 次の条件のどれかを満足すれば，注目画素 $(i, j)$ の $N \times N$ の局所領域すべての画素値を平均し $f(i, j)$ とする.

(1) $\eta\left(\hat{k}_{\max }\right)<\alpha$

(2) $k^{*}=1$ かつ $\hat{k}_{\max }=1$

(3) $k^{*}=M$ かつ $\hat{k}_{\max }=M-1$

ここに， $\alpha$ はあらかじめ定めた閾值である.

手順 7 手順 6 のどの条件も満足しなければ次の処理を する。

(1) $k^{*} \leqq \hat{k}_{\max }$ であれば, $k=1$ から $\hat{k}_{\text {max }}$ ま での $h(k)$ がもつ座標值が示す画像 $f$ の值を 平均し $f(i, j)$ とする.

(2) $k^{*}>\hat{k}_{\text {max }}$ であれば, $k=\hat{k}_{\text {max }}+1$ から 
表 1 処理過程における標準偏差

Standard deviation at each processing.

\begin{tabular}{r|c|r|r|r}
\hline \hline & $f$ & Smoothing & SLCA(1) & SLCA(3) \\
\hline Character area & 26.84 & 9.95 & 5.39 & 4.19 \\
\hline Background & 36.19 & 5.79 & 4.28 & 3.61 \\
\hline
\end{tabular}

$M$ までの $h(k)$ がもつ座標值が示す画像 $f$ の

值を平均し $f(i, j)$ とする.

このアルゴリズムでは「注目画素を中心とした局所領 域には高々 $2 つ 0$ 質の異なった画素群が存在する」とい う仮定を設けている. 手順 1 で色值を局部的に濃淡值に 変えている理由は, 多くのカラー文書画像では文字の色 とその背景色に濃度差が存在するからである。しかしな がら, 本研究の目的は網点ノイズを除去して見た目の色 を得ることにあるので, 従来手法 ${ }^{4)}$ のように前もってカ ラ一画像を濃淡画像に変換してから処理することはしな い. 手順 4 と手順 5 は大津の判別閾值選定法 ${ }^{5)}$ を利用し ている. 手順 6 の 3 つの条件のうち，(1) は 2 群の分布 に差がない場合であり，局所領域を単純に平均する。(2) と (3) は 1 つ群を構成している要素が注目画素だけな のでノイズとして処理することを意味している．実験結 果を次に示す.

付·図 3(a) は光学解像度 1600dpi のスキャナES を用 い400dpi で入力した画像 $(400 \times 400$ 画素) である. (a) の口印の部分を拡大した画像が (b) であり, $3 \times 3$ のマス クで平滑化した前処理結果に画像処理ソフトPhotoshop を用いてロの部分を同率で拡大した画像が (c)である. この前処理が必要な理由は付. 図 3 のように文字領域と 背景領域が同系色の場合，網点の色がアイランド状に 残ることを防ぐためである。また (c)より，この段階で 閾值による 2 值化が可能のように見えるが，それは適 切ではない。 なぜならば, (c) は画像の一部であり, い ろいろな状況が画像には含まれているからである。(d) は (c) に対し $N=3$ として SLCA アルゴリズムを実行 した画像の同じ $\square$ の部分を示している. 文字と背景の 境界部において, $3 \times 3$ の局所領域では平均をとるため の画素数が少なく平滑化の効果が得にくい. そこで (c) に 3 回 SLCA アルゴリズムを施した結果を (e) に示す. (d),(e) から徐々に境界部が明確になり，かつ平滑化が進 んでいることが確認できる。(f) は SLCA を 3 回適用し た画像である。この画像の処理過程における文字部之 背景部の標準偏差を表 1 に示す. 文字部および背景部は 境界部を含まない同一の領域を指定して測定した。な お, $f$ は原画像, Smoothing は前処理した画像を表し, SLCA(1),SLCA(3) はSLCA アルゴリズムをそれぞれ 1 回, 3 回適用した画像から求めた結果を表している. 表 において標淮偏差は R,G,B の各色ごとに表示すべきで あるが, 図 2 における表示と同じ理由で, 色值を濃淡值 に変換して求めた標準偏差を示した.
付·図 3(g) は同じ 400dpi で取得した別の画像 $(400 \times$ 400 画素) であり，(h) は (g)の口の部分を拡大した画像 である。(i) は前処理を施した後 SLCA アルゴリズムを 3 回適用した画像であり，(j) は (h) と同じ部分を拡大し た画像である。前例と同じく境界部の明確化が進みかつ 平滑化されていることが確認できる。しかし，このアル ゴリズムが局所処理であるため境界部に中間色の領域が 多少生じている.

本アルゴリズムで注意すべき点は閾值 $\alpha$ の選び方であ る. $\alpha$ を大きくすると選択性が薄れ単なる平滑化になり, $\alpha$ を小さくすると選択性が強くなる. 本実験では $\alpha=4$ としたが, 適切な $\alpha$ の值は, 手順 6 で局所領域を単純に 平均化する画素数と手順 7 で 2 分割する画素数の比が, ほぼ画像中の境界画素数の割合に近い值になるようにす ることである。

\section{5.むすび}

本論文では, 高解像度で取得したカラー文書画像の網 点ノイズの軽減手法について述べた．本アルゴリズムで はカラー值をいったん濃淡值に変換しているが，色の異 なった $2 つ の$ 領域が同濃度の関係にあれば濃淡值に変換 することは適切ではなく, カラー空間での分布の違いを 評価しなければならない。また, 同種のカラー文書を処 理する場合は事前実験により閾值 $\alpha$ を決定できるが，不 特定のカラー文書を対象にする場合にはこれを事前に決 めることは困難である.今後この点について検討を加え たい.

\section{[文献〕}

1）一ノ瀬修一：“スキャナの最新技術”，情報処理,39, 8, pp.769-775 (1998)

2) A.Rosenfeld.A.C.Kak, 長尾真訳: “ディジタル画像処理”。近代科学 社,pp. 203-204 (1978)

3）後藤英昭，平山理継，阿曾弘具：“局所多值しきい值処理法に上る濃淡文書 画像からの文字バターンの抽出”, 信学論,J82-D-II, 11, pp.2188-2192 (Nov. 1999)

4）塩 昭夫：“情景中文字の検出のための動的 2 值化処理法”，信学論，J71-D, 5, pp.863-873 (Mar. 1988).

5）大津展之：“判別および最小 2 乗規準に基づく自動しきい值選定法”，信学 論,63-D, 4, pp.349-356 (Apr. 1980 年) 


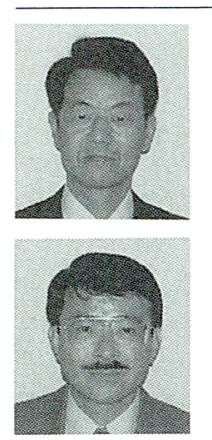

䛫容博衡 1948 年生. 1971 年 3 月富山大学工 学部卒業、同年(模) ぜネラル入社。昭 50 富山大・工。 技官. 現在知能情報工学科助教授。 20 )間視覚生理つ研究, 最近は文字, 文書画像理解, コンピュータビジョンの研究 に従事. 電子情報通信学会, 情報処理学会, 画像電子学会, IEEE 各会員. 工博.

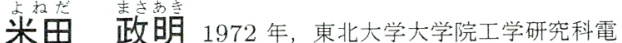
気及通信工学専攻博士課程修了. 同年, 富山大学工学部電 子工学科講師。現在, 同大学工学部知能情報工学科教授. こ の間，オートマトン・言語理論，文字認識・文書画像理解等 の研究に従事. 工学博士。
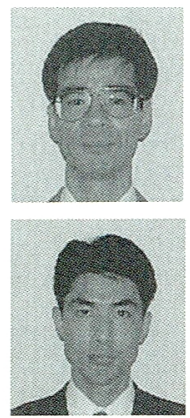

酒井充 昭 54 富山大·工・電子卒, 昭 56 同大 大学院修士課程了. 昭 57 同大·工・技官。現在知能情報工 学科助手。この間，多クラス認識。文字認識，識別関数な どの研究に従事. 電子情報通信学会, 情報処理学会, 人工 知能学会各会員. 工博.

丸山山博 平5 富山大学工学部電子倩報工学科卒 業. 平 7 同大学院工学研究科修士課程修了。同年富山大学 工学部技官. 現在に至る。パターン認識の研究に従事. 電 子情報通信学会, 情報処理学会各会員.

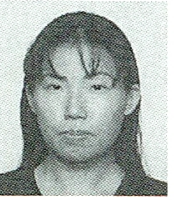

加藤ジェーン 平 2 年名古屋大学大学院修士課程了。 平 5 年同大学院後期課程了。同年富山大学工学部助手。平 11 年オックスフォード大学客員研究員。平 12 年名古屋大 学大学院工学研究科助教授。工博。文書画像理解、パ夕一 ン認識、コンピュータビジョンなどの研究に従事。情報処 理学会、電子情報通信学会、IEEE 各会員。
〈付

録〉
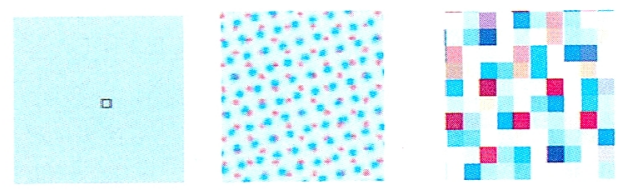

(a) Original image

(b) Enlarged view

(c)Enlarged view(400dpi) (d)Enlarged view(50dpi)

付·図 1 高解像度画像之低解像度画像の比較

Comparison of high and low resolution color images.
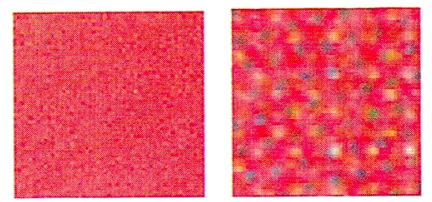

(a)Color 1(rr)
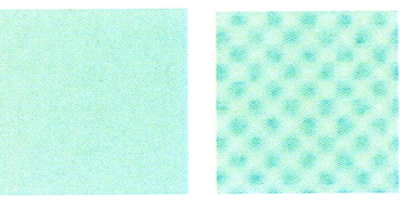

(b)Color 2(gb)

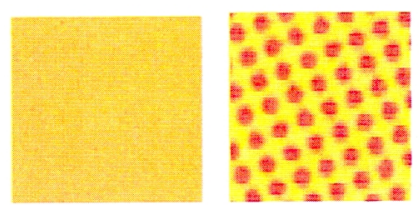

(c)Color 3(yr)

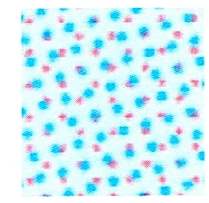

(d)Color 4(lb)

付·図 2 サンプル画像

Sample color images.

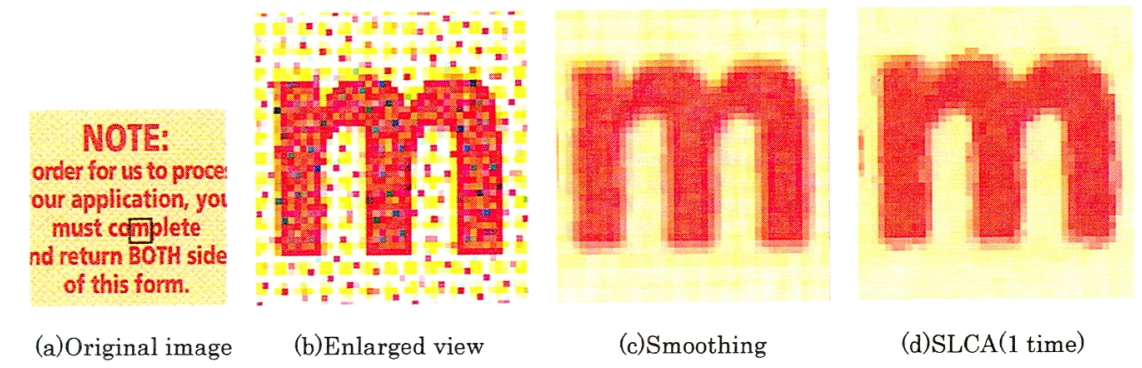

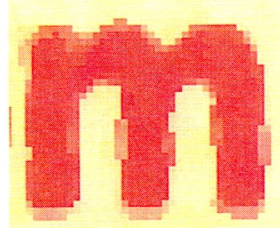

(e)SLCA(3 times)

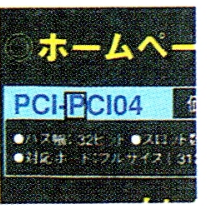

(g)Original image

\section{NOTE:}

order for us to proce: our application, you must complete nd return BOTH side of this form.

(f)SLCA image(3 times)

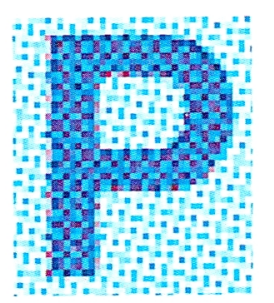

(h) Enlarged view
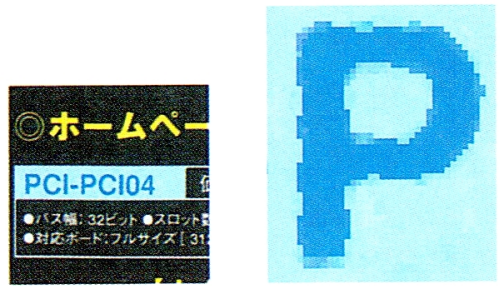

(i)SLCA image(3 times) (j)Enlarged view

付.図 3 選択的局所色平均化

Selective local color averaging 